\title{
The Court Interpreters' Role Perception: The Case of English-Dholuo Interpreters in Subordinate Courts in Nyanza Province, Kenya
}

\section{${ }^{1}$ Peter M. Matu* ${ }^{*}$ Kenneth Odhiambo, ${ }^{2}$ Yakub Adams and ${ }^{2}$ David Ongarora}

\author{
${ }^{1}$ Department of Languages and Communication Studies, The Kenya Polytechnic University College, \\ ${ }^{2}$ Department of Linguistics Maseno University, Kenya.
}

${ }^{*}$ Corresponding Author Email: Mainamatu@ yahoo. com

\begin{abstract}
The objective of this paper is to discuss the perception of court interpreters towards their role in courtroom communication. The paper is based on the premise that court interpreters are influenced by certain roles which they have to adhere to. Based on the concepts of these roles, this paper evaluates the perception of the interpreters in terms of accuracy, omissions, interruptions and impartiality when negotiating between Dholuo and English languages. The paper shows that the interpreters have almost similar perception about their roles.
\end{abstract}

Key words: perception, accuracy, omission, interruption, impartiality.

\section{INTRODUCTION}

This paper aims at discussing the court interpreters' role perception. The issue of role is very important, given the magnitude of responsibility given to the interpreters that necessitate high ethical and language standards. It is therefore important that the court interpreters have a clear comprehension of their role in order to work in harmony with other discourse participants in court.

The role of the interpreters is a complex one. Gonzalez, Vasquez and Mikkelson (1991) state that the court interpreter should provide the legal equivalence via an appropriate interpretation of any statements that are either spoken or read in court. This interpretation should be from the source language to English and vice versa.

Court interpreters are not permitted to provide a summary or a general idea of the original message. They are required to interpret the original source material without editing summarizing, deleting, or adding, while conserving the language level, style, tone and intent of the speaker, or to render what may be termed as the legal equivalence of the source language message (Gonzalez, Vasquez and Mikkelson, 1991). But this is a tricky position for the interpreter given the languages involved and the intention of the speakers.

In order to ensure that the foregoing is adhered to, Gonzalez, Vasquez and Mikkelson (1991) have suggested some of the following as ethical standards for interpreting:

1. The interpreter shall render a complete and accurate interpretation.

2. The interpreter shall remain neutral.

3. The interpreter shall maintain confidentiality.

4. The interpreter shall confine himself to the role of interpreting.

5. The interpreter shall be prepared for any type of proceeding or case.

6. The interpreter shall ensure that the duties of his or her office are carried out, under working conditions that are in the best interest of the court.

7. The interpreter shall be familiar with and adhere to all of the ethical standards and shall maintain high standards of personal and professional conduct to promote public confidence in the administration of justice (Gonzalez et al, $1991 \mathrm{pg}$ 475).

8. In summary, the interpreter should act as a conduit of information in courtroom communication.

In affirming Gonzalez, et al propositions, Kinyanjui (2000:65) states that the court interpreter has '... a duty to interpret the oral evidence, submissions, judicial pronouncements and orders as they are spoken in court or in 
chambers in the course of judicial proceedings or as the judge may direct.... This means that interpretation is an essential component of judicial work and the requirement that all actors in the legal process be linguistically present in the trials. Kinyanjui further notes that the interpreter is required to take an oath on appointment and the oath requires that the interpreter faithfully render the discourse in the courtroom from the source language to the target language.

The court interpreter is therefore seen as a language mediator whose presence and participation allows an individual who does not speak English to meaningfully participate in judicial proceedings. The interpreter therefore has a duty to place the non-English speaking litigant as closely, as is linguistically possible in the same situation as the English-speaking litigant in a legal setting. In so doing the interpreter does not give undue advantage or disadvantage to the non -English speaking litigant.

The court interpreter's responsibility is more than merely to provide an accurate and legally equivalent rendition. The interpreter must be knowledgeable of court procedures for maintaining an accurate and clear record of the proceedings (Gonzalez et al, 1991) The defendant's case rests on the hands of the interpreter and his ability to convey the meaning accurately. If the process of interpretation is faulty, misunderstanding can easily arise that may also affect the outcome of the case. The goals of court interpretation are based on the premise that non English speaking litigants are at a disadvantage, not only because they do not speak the language, but also because they are unfamiliar with the culture and the system. In order to redress this imbalance, it is suggested that interpreters become the advocate of those who do not speak English, and rather than interpret the utterances faithfully, speak on behalf of the non-English speaker. It is against this notion of adhering to the norms of accuracy, omission, interruptions, and impartiality that this paper seeks to describe the interpreters' role perception.

The interpreter's role perception is intertwined with issues of language use in courts in Kenya. In the Kenyan legal system, English is used as the official language of communication. The Judicature Act Cap 8, Section 194 (4) of the Criminal Procedure Code, and Section 86 (1) of the Criminal Procedure Act, state that English shall be the official language of communication in the country's courts. The courts thus assume monolingualism, and hence when dealing with litigants who do not understand English, interpretation is provided for.

Since English is the language of courtroom communication in Kenya, this paper is cognizant of the fact that it is also the language of training for the advocates, magistrates and prosecutors, who encounter non-English speaking litigants. The non-English speaking litigants are disadvantaged and to make sure they effectively participate in their trials, interpreters are provided for.

With English as the official language of courtroom communication, the language of court records will normally be English. Hence the magistrate will heavily rely on the interpreter's efficiency in the process of interpretation to keep an accurate record of the proceedings. The litigants who do not speak English have a right not only to understand the charges against them and the court proceedings, but also to a trial that is substantially in their own language. This serves as the basis for the provision of the court interpreter. It is against this background of a multiplicity of languages that this paper discusses the court interpreters' role perception.

Because this research was carried out in subordinate courts in Kenya, an understanding of the court system in Kenya will suffice at this stage. Kenya has a court structure which operates at two different levels: the High Court and the Subordinate Courts. The courts at each level have power to deal with certain cases which is described as jurisdiction. The courts subordinate to the High Court are established by Section 65(1) of the Constitution of Kenya. The subordinate courts to the High Court are divided into: The Chief Magistrate's Court, The Principal Magistrate's Court, The Resident Magistrate's Court and the District Magistrate's Court. (Kinyanjui, 2000; Lumumba, 2005). These courts are distributed in each of the provinces and districts. They are presided over by magistrates or persons qualified to hold such offices appointed by the Judicial Service Commission.

Lumumba (2005) notes the following about the subordinate courts: The Chief Magistrate's Court has a wide jurisdiction and embraces most crimes. They also have a limited appellate jurisdiction; the Resident magistrate's Court is established by section 3 of the Magistrate's Court Act. Persons appointed must be advocates of High Court of Kenya or hold an equivalent qualification, the District Magistrate's Court is also established by the Magistrate's Court Act (CAP 10). They exercise jurisdiction throughout the districts in respect of which they are established. It is in these subordinate courts that the research was carried out as they are situated in every district. This paper reports on the interpreter's perception of their role in Nyanza province, Kenya.

\section{METHODOLOGY}

The purpose of this paper was to evaluate the perception of the interpreters towards the roles and goals of the interpreter in courtroom conversation. A survey design was used to collect data used in this study. The research area in this study is drawn from the subordinate courts in Nyanza Province of Kenya. Nyanza Province is one of the eight (8) provinces in Kenya which include Nairobi, Western, Rift Valley, Eastern, Central, Coast and North Eastern. 
Nyanza Province had eleven Districts at the time this research was being carried out. The districts are: Kisii Central, Kisii North, Kisii South, Kuria, Migori, Homabay, Rachuonyo, Nyando, Kisumu, Siaya, and Bondo. The research sites were the magistrates' courts in Nyando, Bondo, Siaya, Rachuonyo, and Migori. The choice of the courts is informed by the fact that the residents in these districts are functionally bilinguals but with very strong affinity to their mother tongue (Dholuo). This means that they will tend to use Dholuo in courtroom communication and hence use the services of an interpreter.

The participants consisted of 10 court interpreters in selected subordinate courts in Nyanza province selected through purposive sampling. A questionnaire was administered to the interpreters to elicit information on their perception of accuracy, omission, interruption and impartiality. The responses categories on the items were on a 4point scale of strongly agree, agree, strongly disagree and disagree. A frequency and percentage analysis were performed to determine the perceptions of the interpreters.

\section{RESULTS AND DISCUSSION}

\section{Accuracy}

The notion of accuracy has varied meaning to several scholars. Giles (1991) sees accuracy as associated with the product oriented perspective and focuses primarily on the interpretation as faithful image while Jones (1998) sees accuracy from the perspective of exact or faithful reproduction of the original discourse. Based on the postulation of the two authors it can be deduced that accuracy relates to the aspect of discourse which could be described as comprehensibility. The interpreter is therefore expected to represent fully the original speakers' intention.

An interpreter's main ethical and linguistic responsibility is to maintain the legal equivalence of source language in the target language. Hale (2004) explains that different scholars have different views on the importance of maintaining accuracy. On the one hand, there are those who believe in maintaining accuracy of propositional content alone with liberties to change style and register (Barsky, 1996) ; on the hand, there are those who are for literal verbatim interpretation (Benmaman, 2000).

Table 1 contains statements on accuracy. There were three statements that the interpreters were supposed to react to. The first statement was that interpreters should clarify issues for the participants in dialogue in court. The second statement was that interpreters should interpret only what the speaker says and the third statement was that interpreters should explain the context of the speaker's utterance.

Table 1: Accuracy

\begin{tabular}{|l|l|l|l|l|l|l|l|l|}
\cline { 2 - 8 } \multicolumn{1}{c|}{} & \multicolumn{9}{c|}{ Strongly agree } & Agree & \multicolumn{2}{l|}{ Strongly disagree } & \multicolumn{2}{l|}{ Disagree } \\
\cline { 2 - 8 } \multicolumn{1}{c|}{ Siscourse strategy } & Freq & Per & Freq & Per & Freq & Per & Freq & Per \\
\hline $\begin{array}{l}\text { 1clarifies issues for } \\
\text { the participants in } \\
\text { court discourse }\end{array}$ & 1 & $10 \%$ & 8 & $80 \%$ & - & - & 1 & $10 \%$ \\
\hline $\begin{array}{l}2 \quad \text { interprets only } \\
\text { what the speaker } \\
\text { says }\end{array}$ & 4 & $40 \%$ & 4 & $40 \%$ & 2 & $20 \%$ & & \\
\hline $\begin{array}{l}3 \quad \text { Explains the } \\
\text { context of the } \\
\text { speakers utterance }\end{array}$ & 3 & $30 \%$ & 7 & $70 \%$ & - & - & - & - \\
\hline
\end{tabular}

The interpreters were asked if they should clarify issues for the participants in dialogue in court. When the frequency of the responses was worked out, 10\% returned a rating of STRONGLY AGREE and $80 \%$ returned a rating of AGREE. This overwhelming majority shows that the interpreters do see the need to clarify issues for the Dholuospeaking litigants. The interpreters were also asked if they should interpret only what the speaker says. In this case, $40 \%$ STRONGLY AGREE and $40 \%$ AGREED. A total of $20 \%$ returned a rating of DISAGREE with this statement. The third statement asked if the interpreters should explain the context of the speakers' utterance. In this case $30 \%$ STRONGLY AGREE while 70\% AGREE with the statement. The percentages in accuracy imply that the interpreters desire that the litigants understand almost all of the communication in court. 


\section{Omissions}

Omission is a strategy in which the interpreter generates fewer amount of target speech. This technique enables the interpreter to generate the target speech in shorter time (Tohyama and Matsubara, 2005). They therefore see omission as a discourse strategy that works to the advantage of the interpreter.

Table 2 is an assessment of the use of omissions in interpretation. Using the ratings given, $10 \%$ of the interpreters STRONGLY AGREE and 30\% AGREE with the statement that interpreters sometimes omit some of the speakers' utterances. 30\% of the interpreters STRONGLY DISAGREE and 30\% DISAGREE with the position that they should sometimes omit some of the speakers' utterances. This implies that the majority of the interpreters do not desire to omit some utterances by the speakers. In terms of oral legal communication, the interpreter is expected to render al the utterances by the speakers.

Table 2: Omissions

\begin{tabular}{|l|l|l|l|l|l|l|l|l|}
\cline { 2 - 8 } \multicolumn{1}{c|}{} & \multicolumn{9}{c|}{ Rating } \\
\cline { 2 - 9 } \multicolumn{1}{c|}{} & Strongly Agree & Agree & \multicolumn{3}{l|}{ Strongly Disagree } & \multicolumn{2}{l|}{ Disagree } \\
\hline Discourse Strategy & Freq & Per & Freq & Per & Freq & Per & Freq & Per \\
\hline $\begin{array}{l}\text { Omit some of the } \\
\text { speakers' utterance }\end{array}$ & 1 & $10 \%$ & 3 & $30 \%$ & 3 & $30 \%$ & 3 & $30 \%$ \\
\hline
\end{tabular}

\section{Interruptions}

Rodrigo (2009) notes that in verbal interactions that occur in court, moments of silence between each person's speeches are irrelevant in most cases, and that overlaps in speech are very common. She also notes that a trial is a communicative context in which turn-taking is pre-determined. She defines interruptions as interventions originating from agents (people) that are part of a conversation. She notes that judicial acts in terms of interruptions are fragments of turn-taking in which interrogations are produced.

There were two statements that were asked concerning interruptions. The first statement was that interpreters should interrupt the speakers on the floor and the second was that interpreters should become active participants in court discourse.

In Table 3 the interpreters were asked about interruptions of speakers. A total of $10 \%$ of the interpreters STRONGLY AGREE and 60\% AGREE that they interrupt the speaker on the floor. Another $20 \%$ STRONGLY DISAGREE and $10 \%$ DISAGREE with the statement.

The interpreters were also asked if they should become active participants in courtroom discourse. When the frequency of the responses was worked out, 20\% STRONGLY AGREE and 30\% AGREE, while a similar percentage STRONGLY DISAGREE and DISAGREE. This indicates that the interpreters were not clear as to whether they should actively participate in courtroom discourse or not.

Table 3: Interruptions

\begin{tabular}{|l|l|l|l|l|l|l|l|l|}
\cline { 2 - 8 } \multicolumn{1}{c|}{} & \multicolumn{9}{c|}{ Rating } \\
\cline { 2 - 9 } \multicolumn{1}{c|}{} & Strongly agree & \multicolumn{1}{l|}{ Agree } & Strongly disagree & \multicolumn{2}{l|}{ Disagree } \\
\hline $\begin{array}{l}\text { Discourse } \\
\text { strategy }\end{array}$ & Freq & Per & Freq & Per & Freq & Per & Freq & Per \\
\hline $\begin{array}{l}\text { Should interrupt } \\
\text { the speaker on } \\
\text { the floor }\end{array}$ & 1 & $10 \%$ & 6 & $60 \%$ & 2 & $20 \%$ & 1 & $10 \%$ \\
\hline $\begin{array}{l}\text { Should become } \\
\text { active participant } \\
\text { in court discourse }\end{array}$ & 2 & $20 \%$ & 3 & $30 \%$ & 2 & $20 \%$ & 3 & $30 \%$ \\
\hline
\end{tabular}




\section{Impartiality}

Zimanyi (2009), notes that the discussion of the role of the interpreter considers the notion of role in terms of the interpreters' involvement with either of the primary participants of the interpreter-mediated encounter. Zimanyi further notes that the interpreters can align themselves with service users. This would be ranked as being partisan. On the other hand the Administrative Office of the United States Courts (1996) state that interpreters shall be impartial and unbiased and shall refrain from conduct that may give an appearance of bias. It further states that the interpreter should avoid any conduct or behaviour that presents the appearance of favouritism towards any party.

Because court interpreters in Kenya work in an adversarial system, there is danger that they may be perceived as advocates for the party they are interpreting for in a given case, hence the need to maintain neutrality.

Wadensjo (1998) explains that the role of the interpreter is normally considered to be one of non-involvement. She also argues that both communication and miscommunication entail a reciprocal interaction between those involved in a given interaction. Wadensjo's position is that the interpreters take on not only the role of translators, but also of active builders and processors of speech inevitably influencing the speech itself.

Table 4: Impartiality

\begin{tabular}{|c|c|c|c|c|c|c|c|c|}
\hline & \multicolumn{8}{|c|}{ Rating } \\
\hline & \multicolumn{2}{|c|}{ Strongly agree } & \multicolumn{2}{|c|}{ Agree } & \multicolumn{2}{|c|}{ Strongly disagree } & \multicolumn{2}{|c|}{ Disagree } \\
\hline Discourse strategy & Freq & Per & Freq & Per & Freq & Per & Freq & Per \\
\hline $\begin{array}{l}\text { Mediate message in } \\
\text { broader sense }\end{array}$ & 2 & $20 \%$ & 6 & $60 \%$ & 1 & $10 \%$ & 1 & $10 \%$ \\
\hline $\begin{array}{l}\text { Have relationship } \\
\text { with Dholuo- } \\
\text { speaking litigants }\end{array}$ & 2 & $20 \%$ & 3 & $30 \%$ & 3 & $30 \%$ & 2 & $20 \%$ \\
\hline $\begin{array}{l}\text { Intervene where } \\
\text { there is } \\
\text { miscommunication }\end{array}$ & 2 & $20 \%$ & 8 & $80 \%$ & - & - & - & - \\
\hline
\end{tabular}

Table 4 dealt with the issues of impartiality. There were three items that the interpreters were expected to react to. The first statement was that the interpreters should mediate the message in a broader sense. The second and third statements were that the interpreters should have a closer relationship with the Dholuo-speaking litigants and that the interpreter should intervene where there is miscommunication respectively.

In Table 4, the interpreters were asked if their role in court was to mediate the message in a broader sense. An overwhelming $60 \%$ AGREE with the statement and 20\% STRONGLY AGREE while a paltry $10 \%$ STRONGLY DISAGREE and another $10 \%$ DISAGREE.

Still on impartiality, the interpreters were asked if there is a closer relationship between the Dholuo -speaking litigants and the interpreters. 20\% of the interpreters STRONGLY AGREE and AGREE with this statement, while another $10 \%$ STRONGLY DISAGREE and DISAGREE. This pattern of response where $10 \%$ agree and $10 \%$ disagree is consistent with the fact that there is a desire to aid the Dholuo-speaking litigant and at the same time remain impartial.

Table 4 was a response to the statement that the interpreters should intervene where there is miscommunication. 20\% STRONGLY AGREE and 80\% AGREE with this statement. This is the only case in which all the interpreters agree with a statement. The fact that none of the interpreters either disagree or strongly disagree with the statement, gives a strong indication that there exists a conscious effort to solve communication problems in the court.

The aim of this paper was to evaluate the interpreter's perception of their role. The data recorded, points to the direction that the interpreters have a positive perception of their role.

The interpreters perceptions of roles and goals presented above are indications that the interpreters have varied perceptions of their roles. While interpreting in court, therefore, the interpreter should select user-friendly roles. This involves the question of which role to choose from so that information is received by all the discourse participants. The analysis above thus demonstrate that the interpreters desire to add more information, not desire to omit, desire to interrupt and desire to be impartial in their interpretation. The rating of addition may be attributed to the fact that oral legal discourse is goal-oriented and if not fully understood, it may impact negatively on any of the discourse participants. This is in tandem with Berk-seligson (1992) who demonstrates that some of the court interpreters in American courtrooms lengthened witness testimonies by including linguistic materials in their English 
renditions which were not present in the Spanish utterances. This view is supported by Wadensjo (1992) who also provides examples of expanded renditions that were meant to disambiguate some utterances.

The data on omissions collected for this paper suggest that the interpreters in practice do not desire to omit any utterance from the speaker. While the interpreters reported that they should not omit any utterance from the speaker, data from the linguistic strategies show that they indeed omitted some utterances. The result on omission seems to be concordant with Gonzalez et al (1991) who support the view that the interpreter should not omit any utterance.

The case of impartiality paints an interesting picture. A majority of the interpreters agree that the interpreter should remain impartial. Because the court interpreter's work in an adversarial system, there is danger that they will be perceived as advocates for the party they are interpreting for in a given case. In support of impartiality, Hewitt (1995) notes that the court interpreter is expected to remain neutral and objective at all times.

In terms of interruption the data collected in this study is even more explicit. It was observed from the data that a majority of the interpreters reported that they could interrupt the speaker on the floor.

\section{Conclusion}

The paper set out to evaluate the interpreters' perception of their role. The article reviews the roles and goals of the court interpreter in Kenya from the position of Gonzalez et al and also provides information about language use in courts in Kenya as well as the court structure in Kenya. The paper shows that the interpreters have a great responsibility to understand, appreciate and value their role. This is supported by the data that an overwhelming majority both agree and strongly agree with issues of accuracy, omission, interruptions and impartiality. The interpreters have to react to their role in almost the same way to enable them perform their tasks in a uniform way.

\section{References}

Administrative Office of the United States Courts (1996) Federal Court Interpreter Policies and Procedures

Barsky, R. (1996). The interpreter as cultural agent in convention refugee hearings. The Translator, 2, (1): $45-6$.

Benmaman, V. (2000). Interpreter issue on Appeal. NAJIT Fall 2000 Vol 1X No. 4

Berk-Seligson, S. (1990/2002). The Bilingual Courtroom; Court Interpreters in the Judicial System. Chicago:University of Chicago Press.

Giles, D. (1991) A Communication-oriented Analysis of Quality in Non-literary Translation and Interpretation. In Larson M.L. (ed) Translation: Theory and Practice. Tension and Interdependence. Birghamton NY: Sunny pg 188200

Gonzalez R ., Vasquez, V., and Mikkelson,H. (1991). Fundamentals of court Interpretation: Theory, Policy and Practice. Durham, North Carolina: Carolina Academic Press.

Government of Kenya. (1998) The Constitution of Kenya (Revised Edition). Nairobi: Government Printer.

Government of Kenya Laws of Kenya. (1987). The Criminal Procedure Code (Revised Edition). Nairobi: Government Printer.

Hale, S.B (2004). The Discourse of Court Interpreting: Discourse Practices of the Law, the Witness, and the Interpreter. Amsterdam/ Philadelphia: John Benjamins.

Hewitt, W. E. (1995). Court Interpretation: Model Guides for Policy and Practice in the States Courts. Williamburg, UA: National Center for State Courts.

Jones, R. (1998). Conference Interpreting Explained. Manchester. St Jerome Publishing.

Kinyanjui, K.(2000). How Our Court Works: The Administrative Practice of KenyanCourts. Nairobi: Transafrica Press. Lumumba, P.L.O (2005). A Handbook on Criminal Procedure in Kenya. Kampala: LawAfrica Publishing (T) Limited.

Rodrigo, S.R. (2009). The Process of interruption in Spanish Judicial Context: A Pragmalinguistic Approach. Tejuelo No 7 pp8-43.

Tohyama, H. and Matsubara, S. (2005). Construction and utilization of Bilingual Speech Corpus for Simultaneous machine Interpretation Research, Proc. Eurospeech pp1585 - 1588

Wadensjo, C. (1998). Interpreting as Interaction. London/New York: Longman.

Zimanyi, K. (2009). On Impartiality and Neutrality: a diagrammatic tool as a visual aid. The International Journal for Translation and Interpreting Research. Vol. 1 No 2 pg 55-70 